\title{
Captive wildlife from India as carriers of Shiga toxin-producing, Enteropathogenic and Enterotoxigenic Escherichia coli
}

\author{
Arockiasamy Arun Prince MILTON ${ }^{1)}$, Rajesh Kumar AGARWAL ${ }^{2) *}$, \\ Govindarajan Bhuvana PRIYA ${ }^{2)}$, Manivasagam ARAVIND ${ }^{3)}$, \\ Cheruplackal Karunakaran ATHIRA ${ }^{1)}$, Losa ROSE ${ }^{2)}$, Mani SAMINATHAN ${ }^{4}$, \\ Anil Kumar SHARMA ${ }^{4)}$ and Ashok KUMAR ${ }^{5)}$ \\ 1)Division of Veterinary Public Health, Indian Council of Agricultural Research (ICAR)-Indian Veterinary \\ Research Institute, Izatnagar, Bareilly-243122, Uttar Pradesh, India \\ ${ }^{2)}$ Division of Bacteriology and Mycology, Indian Council of Agricultural Research (ICAR)-Indian Veterinary \\ Research Institute, Izatnagar, Bareilly-243122, Uttar Pradesh, India \\ ${ }^{3)}$ Department of Veterinary Parasitology, Madras Veterinary College, Chennai-600007, Tamil Nadu, India \\ ${ }^{4)}$ Division of Pathology, Indian Council of Agricultural Research (ICAR)-Indian Veterinary Research Institute, \\ Izatnagar, Bareilly-243122, Uttar Pradesh, India \\ 5)Division of Animal Science, Indian Council of Agricultural Research (ICAR), Krishi Bhavan, New Delhi, India
}

J. Vet. Med. Sci.

81(2): 321-327, 2019

doi: 10.1292/jvms.18-0488

Received: 17 August 2018

Accepted: 13 October 2018

Published online in J-STAGE:

2 November 2018

\begin{abstract}
Shiga toxin-producing Escherichia coli (STEC), Enteropathogenic E. coli (EPEC), and Enterotoxigenic E. coli (ETEC) make up an important group of pathogens causing major animal and public health concerns worldwide. The aim of this study was to determine the prevalence of different pathotypes of $E$. coli in captive wildlife. We analyzed 314 fresh fecal samples from captive wildlife, 30 stool swabs from animal caretakers, and 26 feed and water samples collected from various zoological gardens and enclosures in India for the isolation of E. coli, followed by pathotyping by multiplex PCR. The overall occurrence rate of $E$. coli was $74.05 \%(274 / 370)$. The 274 E. coli isolates were pathotyped by multiplex PCR targeting 6 genes. Of them, $5.83 \%$ were pathotyped as EPEC, $4.74 \%$ as STEC, and $1.09 \%$ as ETEC. The 16 S rRNA genes from the selected isolates were amplified, sequenced, and a phylogenetic tree was constructed. The phylogenetic tree exhibited indiscriminate genetic profiling and some isolates from captive wild animals had $100 \%$ genetic identity with isolates from caretakers, suggesting that captive wildlife may serve as a reservoir for infection in humans and vice-versa. The present study demonstrates for the first time the prevalence of these $E$. coli pathotypes in captive wildlife in India. Our study suggests that atypical EPEC strains are more frequent than typical EPEC strains in captive wildlife. Discovering the implications of the prevalence of these pathotypes in wildlife conservation is a challenging topic to be addressed by further investigations.

KEY WORDS: captive wildlife, Enteropathogenic E. coli (EPEC), Enterotoxigenic E. coli (ETEC), India, shiga-toxin producing Escherichia coli (STEC)
\end{abstract}

One Health approaches play a vital part in the management and protection of human, livestock, wildlife, and environmental health [16]. While significant progress has been made in furthering our understanding of underlying disease processes, our knowledge of pathogen control at the livestock-wildlife interface remains minimal [25]. The excretion of pathogens in the feces of captive wild animals in zoos poses several health hazards through environmental contamination, resulting in the morbidity and mortality of other animals as well as economic losses to the zoo itself [17]. There is typically a dearth of information on pathogen incidence and transmission in captive and free-range wildlife population, with the only exception being when pathogenic activity within these population poses a threat to humans or valued animal population.

Animals living in zoos or bred in semi-free-range areas may become infected with enteric pathogens while in their enclosures [1]. Escherichia coli is a facultative anaerobe, and although an innocuous resident of the intestinal tract of humans and other warm-blooded animals, it has the potential to cause significant diarrheal and extraintestinal diseases [6]. E. coli strains associated with diarrhea are collectively referred to as diarrheagenic E. coli (DEC), a grouping comprising enteropathogenic E. coli (EPEC),

*Correspondence to: Agarwal, R. K.: grace_bly@yahoo.com

O2019 The Japanese Society of Veterinary Science

This is an open-access article distributed under the terms of the Creative Commons Attribution Non-Commercial No Derivatives (by-nc-nd) License. (CC-BY-NC-ND 4.0: https://creativecommons.org/licenses/by-nc-nd/4.o/) 
enterohemorrhagic E. coli (EHEC), enterotoxigenic E. coli (ETEC), enteroinvasive E. coli (EIEC), enteroaggregative E. coli (EAEC), and diffuse-adherent E. coli (DAEC) [5]. Although pathogenic E. coli is extensively studied in humans, farm animals, food, and the environment, it is not well studied in wildlife.

EPEC infection can result in attaching and effacing (A/E) lesions and EPEC strains can be categorized as either "typical" or "atypical" based on the presence or absence of $E$. coli adherence factor plasmids, which contain the cluster of genes encoding bundle-forming pili (bfp) [32]. Humans are the only known reservoir for typical EPEC strains, being carried by asymptomatic adults and both symptomatic and asymptomatic children [13]. Atypical strains have been isolated from both humans and animals, including sheep, dogs, rabbits and monkeys [20,30]. Several human and animal EPEC strains are clonally related and share various virulence characteristics [20]. The outcome of STEC infection ranges from asymptomatic carriage to diarrhea to more severe symptoms including hemorrhagic colitis (HC) and hemolytic-uremic syndrome (HUS). Owing to their human pathogenicity, some STEC strains are classified as enterohemorrhagic E. coli (EHEC). EHEC strains comprise a subgroup of STEC and are characterized by certain serotypes, which are frequently associated with outbreaks and severe clinical illnesses [22]. EHEC strains are currently considered to have evolved from EPEC strains through the acquisition of bacteriophages encoding stx [24, 34]. Ruminants, especially dairy and meat cattle are known to be the primary reservoirs for EHEC and exposure to their fecal matter constitutes an important source of human infection [9]. ETEC, which is endemic in most underdeveloped countries, is a major cause of traveler's diarrhea, diarrhea in infants, and colibacillosis in calves and piglets [23]. Contaminated food and water and direct contact with an infected person or animal are the most common sources of infection [31]. ETEC toxins (LT \& ST) are associated with ETEC strains and strains are typically produce either LT or ST or both LT \& ST. Globally, 60\% of isolates expressed LT either alone (27\%) or in combination with ST (33\%) [10]. In most developing countries, and especially in India, little is known about the presence of $E$. coli pathotypes in wildlife. With this in mind, the present study aimed to investigate the prevalence of STEC, EPEC, and ETEC in captive wild animals, their caretakers, and their feed and water in different regions across India and to decipher the phylogenetic relationships between the recovered isolates.

\section{MATERIALS AND METHODS}

\section{Study area}

The study was carried out in 4 zoological gardens and wildlife enclosures, viz., Kanpur Zoo, Kanpur, Uttar Pradesh; Nainital Zoo, Nainital, Uttarakhand; Deer Park, Indian Veterinary Research Institute, Izatnagar, Bareilly, Uttar Pradesh; and the Post Graduate Research Institute of Animal Sciences, Chennai, Tamil Nadu, India.

\section{Sample description}

A total of 370 samples were obtained, comprising the fresh fecal samples of 314 healthy captive animals (40 species), 30 stool swabs from animal caretakers, and 26 feed and water samples. To obtain fecal samples, approximately $10 \mathrm{~g}$ of fecal matter was collected from clinically healthy animal using gloves and Cary-Blair transport media (Himedia, Mumbai, India). Caretakers were given sterile swabs to collect stool samples. The samples were placed in a chilled box, transported to the laboratory, and processed immediately.

\section{Isolation, identification, and confirmation of E. coli}

Approximately $1 \mathrm{~g} / \mathrm{m} l$ of each sample (fecal pellet/feed/water) was suspended in $9 \mathrm{~m} l$ of MacConkey broth (Himedia, Mumbai, India) and incubated overnight at $37^{\circ} \mathrm{C}$. After enrichment, $10 \mu \mathrm{l}$ of the product was streaked onto eosin methylene blue (EMB) agar (Himedia) and incubated $\left(37^{\circ} \mathrm{C}, 24 \mathrm{hr}\right)$. Up to three dark colonies with a green metallic sheen were picked and separately subcultured on EMB agar for $24 \mathrm{hr}$ at $37^{\circ} \mathrm{C}$ for purification. Purified strains were further identified using gram-staining and a HilMViC biochemical kit (Himedia). Isolates were grown on LB broth (Difco Labs, Detroit, MI, U.S.A.) for 18 hr, after which the genomic DNAs of all the isolates were extracted using a QIAamp DNA Mini Kit (Qiagen, Hilden, Germany). To confirm the isolates' identities as E. coli, species-specific PCR was employed using a previously reported protocol [26].

\section{Pathotyping}

The DNA of all the confirmed E. coli isolates were further subjected to previously reported PCR protocols [33] for the identification of pathotypes. The targeted pathotypes (genes) were shiga toxin-producing ( $s t x_{1}$, stx $x_{2}$, and eae), typical enteropathogenic (eae and $b f p$ ), atypical enteropathogenic (eae), and enterotoxigenic (stII and $l t) E$. coli. PCR primers specific to $s t x_{1}$ and $s t x_{2}$ have previously been described by Cebula et al. [4], and those specific to eae, bfp, stII, and $l t$ have been described by Vidal et al. [33]. The diarrheagenic E. coli reference strains EH18D (stx $s_{1}$ t $x_{2}$ eae), ET12C (lt), ET117C (stII), and EP72D (eae and $b f p$ ) from our laboratory were used as positive controls. The positive control DNAs were pooled for multiplex PCR analysis to detect virulence genes $\left(s t x_{1}, s t x_{2}, e a e, b f p, s t I I\right.$, and $\left.l t\right)$.

\section{Phylogenetic analysis}

We selected isolates from various sources irrespective of their pathotypes using a random number table generated in Microsoft Excel $^{\mathrm{TM}}$, giving due weightage to the number of isolates from a particular source. We selected five isolates each from ruminants, non-ruminants, birds, and caretakers and three isolates from feed and water sources. The 16S rRNA genes of the selected 23 E. coli isolates from various sources were amplified by PCR [18]. Sequencing of the amplified 16S rRNA genes of the selected isolates was 
outsourced to Eurofin, Bangalore, India, to whom we provided purified PCR products obtained using a QIAquick PCR Purification Kit (Qiagen, Hilden, Germany). The obtained sequences were analyzed using Gene Tool, DNA Star, Chromas Lite, and MEGA version 6.0, in which multiple sequence alignment was performed and percent identities and phylogenetic trees were retrieved. The edited sequences were subjected to multiple alignment using ClustalW and a pairwise distance comparison was performed with bootstrapping (1,000 replications) throughout the analysis and a neighbor-joining (NJ) phylogenetic tree was constructed using the distance algorithms in the MEGA6 package. The nucleotide sequences were deposited in GeneBank using the National Centre for Biotechnology Information (NCBI, Bethesda, MD, U.S.A.) Bankit submission tool (http://www3.ncbi.nlm.nih.gov).

\section{RESULTS}

Microbiological, biochemical and PCR analysis of the 370 samples resulted in 274 (74.05\%) positive identifications. A total of 93 isolates from captive wild ruminants $(\mathrm{n}=126), 67$ isolates from captive wild non-ruminants $(\mathrm{n}=86), 79$ isolates from captive wild birds ( $\mathrm{n}=102), 24$ isolates from caretakers' stool samples $(\mathrm{n}=30)$, and 11 isolates from feed and water samples from wildlife enclosures $(\mathrm{n}=26)$ were identified and confirmed as E. coli.

Pathotyping using multiplex PCR analysis of the confirmed E. coli isolates provided the following results. A total of 32 (11.67\%) isolates were successfully pathotyped. Among these $32 \mathrm{E}$. coli isolates, EPEC was found to be the predominant pathotype with an isolation rate of $5.83 \%(16 / 274)$, followed by STEC $(4.7 \%, 13 / 274)$, and ETEC $(1.09 \%, 3 / 274)$. Among the 13 isolates identified as STEC, $3(23 \%)$ carried only $s t x_{1}, 5(38.4 \%)$ only $s t x_{2}, 3(23 \%)$ carried both $s t x_{1}$ and $s t x_{2}$, and $2(15.4 \%)$ carried the $s t x_{1}$ and $s t x_{2}$ genes as well as the eae gene. Of the 16 isolates identified as EPEC, $14(87.5 \%)$ were atypical, bearing only the eae gene, and $2(12.5 \%)$ were typical, bearing both the eae and $b f p$ genes. Of the 3 isolates identified as ETEC, $2(66.7 \%)$ carried only the $l t$ gene and $1(33.3 \%)$ carried only the stII gene. Among EPEC pathotypes, the highest isolation rate $(7.84 \%, 8 / 102)$ was observed in captive wild birds, followed by captive wild non-ruminants $(5.81 \%, 5 / 86)$ and captive wild ruminants $(1.58 \%, 2 / 126)$. Among the 8 isolates recovered from captive wild birds, 7 were found to be atypical EPEC strains, carrying only the eae gene, with one isolate recovered from ostriches being a typical EPEC strain bearing both the eae and $b f p$ genes. Among the 5 isolates recovered from captive wild non-ruminants, all were found to be atypical EPEC strains carrying only the eae gene. Both the isolates recovered from captive wild ruminants were also found to be atypical EPEC strains carrying only the eae gene. Among birds, ostriches were found to be the most likely to harbor EPEC pathotypes with an isolation rate of $14.28 \%(5 / 35)$. Among the 5 EPEC isolates recovered from ostriches, one was found to be a typical EPEC strain carrying both the eae and $b f p$ genes and the remaining four were atypical EPEC strains carrying only the eae gene. Interestingly, one typical EPEC isolate carrying both the eae and $b f p$ genes was also detected in the ostriches' caretaker. Among STEC pathotypes, the highest isolation rate $(7.14 \%, 9 / 126)$ was observed among captive wild ruminants, especially in deer and antelopes. The next-highest isolation rate was in non-ruminants $(3.48 \%$, 3/86), while no STEC pathotypes were found in the sampled birds. Among the 9 STEC isolates recovered from captive wild ruminants, 2 carried all three genes ( $s t x_{1}, s t x_{2}$ and eae), 2 isolates carried both the $s t x_{1}$ and $s t x_{2}$ genes, 3 isolates carried only the stx 2 gene, and the other 2 isolates carried only the $s t x_{1}$ gene. Among ETEC pathotypes, the highest isolation rate was in human caretakers $(6.7 \%, 2 / 30)$, with recovered isolates carrying the $l t$ gene. One ETEC isolate was recovered from black buck $(1 / 17$, $5.88 \%$ ) which carried the $s t I I$ gene. One typical EPEC isolate $(1 / 30,3.33 \%)$ carrying both the eae and $b f p$ genes was isolated from the stool of the ostriches' caretaker and two ETEC (2/30, 6.7\%) isolates carrying the $l t$ gene were recovered from two caretakers at Kanpur zoo. One STEC carrying both $s t x_{1}$ and $s t x_{2}$ was isolated from feed and water samples (1/26, 3.84\%). Species-specific prevalences are listed in Tables 1-3.

The 16S rRNA genes of $23 \mathrm{E}$. coli isolates recovered from a diverse array of sources were amplified, sequenced and submitted to GenBank (see Table 4 for additional information including accession numbers). Of the 23 isolates, 20 isolates were grouped into the same cluster (except for IHD4, NCT5, and KHY5) within which KBB6, KW1, and NL2 formed a separate subcluster, and KHY5 formed a subcluster with previously submitted sequences from the U.S.A., the U.K., and Japan (Fig. 1). Percent identity and divergence determined by analyses using MEGALIGN in DNA star revealed $80.2-100 \%$ identity and a divergence of $0.0-3.2$ between the isolates. Four E. coli isolates from captive wild ruminants (KTD3), captive wild non-ruminants (KJ2), captive wild birds (KSCR2), and animal caretakers (KCT4) from Kanpur zoo exhibited 100\% identity. Two E. coli isolates, viz., KWI and KBB6 also exhibited 100\% identity. Three E. coli isolates from Nainital zoo recovered from a captive wild ruminant (NBD2), a captive wild non-ruminant (NJM1), and an animal caretaker (NCT2) showed $100 \%$ identity.

\section{DISCUSSION}

This study is the first report of EPEC and ETEC strains in zoos in India. Of the 274 tested E. coli isolates, 32 were pathotyped as either STEC, EPEC, or ETEC. Others (232) did not belong to these pathotypes and may be commensal or could belong to other pathotypes not tested for in this study. The lack of studies on $E$. coli pathotypes in captive wildlife is primarily due to the difficulty associated with obtaining samples. The only other study which investigated a similar issue in India evaluated the prevalence of VTEC in deer, reporting an overall prevalence of $9.37 \%$ and the prevalence of strains carrying $s t x_{1}(26.6 \%)$, stx $x_{2}(33.3 \%)$, and both stx $x_{1}$ and $s t x_{2}(20 \%)$ [19]. The prevalences of isolates carrying either $s t x_{1}$ or $s t x_{2}$ or both $s t x_{1}$ and $s t x_{2}$ reported in this study are similar to those reported by this study [19]. The prevalence of the $s t x_{1}$ gene (24\%) reported by another study carried out in Belgium is concordant with our findings [2]. However, higher stx 2 prevalences exceeding $65 \%$ have also been reported by prior studies [28, 29]. The prevalence of the possession of both $s t x_{1}$ and $s t x_{2}$ according to a prior study is $28.6 \%$ [7], slightly higher than the values reported here. In our 
Table 1. Prevalence of E. coli and its pathotypes (STEC, EPEC, and ETEC) in fecal samples collected from captive wild ruminants

\begin{tabular}{|c|c|c|c|c|c|c|c|}
\hline \multicolumn{2}{|c|}{ Captive wild ruminants } & \multirow{3}{*}{ No. of samples } & \multirow{3}{*}{ E. coli } & \multicolumn{4}{|c|}{ Pathotypes } \\
\hline \multirow{2}{*}{ Common name } & \multirow{2}{*}{ Scientific name } & & & \multirow{2}{*}{ STEC } & \multicolumn{2}{|c|}{ EPEC } & \multirow{2}{*}{ ETEC } \\
\hline & & & & & Typical & Atypical & \\
\hline Sambar deer & Rusa unicolor & 5 & 5 & - & - & - & - \\
\hline Himalayan goral & Naemorhedus goral & 8 & 5 & 2 & - & - & - \\
\hline Barking deer & Muntiacus muntjak & 5 & 3 & 1 & - & - & - \\
\hline Thamin deer & Panolia eldii & 10 & 7 & 1 & - & - & - \\
\hline Swamp deer & Cervus duvaucelii & 15 & 11 & - & - & 1 & - \\
\hline Nilgai & Boselaphus tragocamels & 12 & 8 & 1 & - & - & - \\
\hline Spotted deer & Axis axis & 32 & 25 & 3 & - & - & - \\
\hline Blackbuck & Antilope cervicapra & 17 & 13 & 1 & - & - & 1 \\
\hline Indian hog deer & Hyelaphus porcinus & 15 & 12 & - & - & 1 & - \\
\hline Sika deer & Cervus Nippon & 3 & 1 & - & - & - & - \\
\hline Chousinga deer & Tetracerus quadricornis & 2 & 2 & - & - & - & - \\
\hline Himalayan blue sheep & Pseudois nayaur & 2 & 1 & - & - & - & - \\
\hline Total & & 126 & 93 & 9 & - & 2 & 1 \\
\hline
\end{tabular}

Table 2. Prevalence of E. coli and its pathotypes (STEC, EPEC and ETEC) in fecal samples collected from captive wild non-ruminants

\begin{tabular}{|c|c|c|c|c|c|c|c|}
\hline \multicolumn{2}{|c|}{ Captive wild non-ruminants } & \multirow{3}{*}{ No. of samples } & \multirow{3}{*}{ E. coli } & \multicolumn{4}{|c|}{ Pathotypes } \\
\hline \multirow{2}{*}{ Common name } & \multirow{2}{*}{ Scientific name } & & & \multirow{2}{*}{ STEC } & \multicolumn{2}{|c|}{ EPEC } & \multirow{2}{*}{ ETEC } \\
\hline & & & & & Typical & Atypical & \\
\hline Leopard & Panthera pardus & 20 & 16 & 1 & - & 1 & - \\
\hline Bengal Tiger (inc. one white) & Panthera tigris tigris & 9 & 7 & - & - & 1 & - \\
\hline Hyena (striped) & Hyaena hyaena & 10 & 8 & 1 & - & - & - \\
\hline Tibetian wolf & Canis lupus chanco & 2 & 2 & - & - & - & - \\
\hline Jackal & Canis aureus & 5 & 4 & 1 & - & - & - \\
\hline Himalayan black bear & Ursus thibetanus laniger & 7 & 5 & - & - & 1 & - \\
\hline Sloth bear & Melursus ursinus & 2 & 2 & - & - & - & - \\
\hline Hippopotamus & Hippopotamus amphibious & 6 & 4 & - & - & - & - \\
\hline Indian rhinoceros & Rhinoceros unicornis & 3 & 2 & - & - & - & - \\
\hline Gray langur & Semnopithecus entellus & 5 & 5 & - & - & - & - \\
\hline Bonnet macaque & Macaca radiate & 5 & 5 & - & - & 1 & - \\
\hline Rhesus macaque & Macaca mulatta & 3 & 3 & - & - & 1 & - \\
\hline Japanese macaque & Macaca fuscata & 2 & 2 & - & - & - & - \\
\hline Palm civet & Paradoxurus hermaphroditus & 3 & - & - & - & - & - \\
\hline Red panda & Ailurus fulgens & 2 & 1 & - & - & - & - \\
\hline Leopard cat & Prionailurus bengalensis & 1 & 1 & - & - & - & - \\
\hline Zebra & Equus quagga & 1 & - & - & - & - & - \\
\hline Total & & 86 & 67 & 3 & - & 5 & - \\
\hline
\end{tabular}

study, 2 isolates of what is likely EHEC carried both stx and eae [24, 34]. Another study conducted in Argentina found similar results to those reported here, finding prevalences of isolates carrying $s t x_{1}(20 \%)$, stx 2 (15.4\%), and both $s t x_{1}$ and $s t x_{2}(15.4 \%)$ [12]. To the best of our knowledge based on the literature reviewed, this is the first report of STEC in thamin deer, barking deer, nilgai, Himalayan ghoral, leopard, and jackal. However, STEC has previously been reported in spotted deer and blackbuck [12].

The prevalence of EPEC in our study was 5.83\%. In a study of wild cervids in Belgium, 1.5\% (6/399) of EPEC isolates carried only the eae gene [2], lower than in our study. Our study is also concordant with a previous study of captive psittacines in Brazil, where $6.52 \%(3 / 46)$ of typical EPEC isolates carried both the eae and $b f p$ genes [27]. In our study, the prevalence of EPEC among monkeys was $13.3 \%(2 / 15)$. Isolations of EPEC from rhesus and bonnet macaque simian immunodeficiency virus-infected infants and adult rhesus macaques has also been reported [15]. In another study carried out in healthy monkeys, the prevalence of EPEC was $26 \%$, which is higher than our observations [3]. Similar to other studies, atypical EPEC strains were found to be more prevalent than typical strains $[2,11]$, suggesting that atypical EPEC strains are becoming increasingly more frequent relative to typical EPEC strains. Despite the fact that humans are the only known reservoir for typical EPEC strains [13], we were able to isolate typical EPEC from ostriches and from one of their caretakers. Earlier studies also reported typical EPEC in captive psittacines [27] and cats [8]. Our present findings may be valuable in emphasizing that animal caretakers and visitors may serve as both sources and reservoirs in the infection of captive animals by EPEC and vice versa. Thus, we hypothesize that animals which test positive for 
Table 3. Prevalence of E. coli and its pathotypes (STEC, EPEC and ETEC) in fecal samples collected from captive wild birds

\begin{tabular}{|c|c|c|c|c|c|c|c|}
\hline \multicolumn{2}{|c|}{ Captive wild birds } & \multirow{3}{*}{ No. of samples } & \multirow{3}{*}{ E. coli } & \multicolumn{4}{|c|}{ Pathotypes } \\
\hline \multirow{2}{*}{ Common name } & \multirow{2}{*}{ Scientific name } & & & \multirow{2}{*}{ STEC } & \multicolumn{2}{|c|}{ EPEC } & \multirow{2}{*}{ ETEC } \\
\hline & & & & & Typical & Atypical & \\
\hline Silver pheasant & Lophura nycthemera & 8 & 6 & - & - & - & - \\
\hline Cockatiel & Nymphicus hollandicus & 6 & 5 & - & - & - & - \\
\hline Lady Amherest Pheasant & Chrysolophus amhersitae & 12 & 9 & - & - & 1 & - \\
\hline Sun conure & Aratinga solstitialis & 6 & 3 & - & - & - & - \\
\hline Red Jungle fowl & Gallus gallus & 2 & 2 & - & - & - & - \\
\hline Indian peafowl & Pavo cristatus & 4 & 3 & - & - & 1 & - \\
\hline White peafowl & Pavo cristatus mut. alba & 3 & 3 & - & - & - & - \\
\hline Saras crane & Grus antigone & 5 & 4 & - & - & 1 & - \\
\hline Emu & Dromaius novaehollandiae & 5 & 4 & - & - & - & - \\
\hline Total & & 102 & 79 & - & 1 & 7 & - \\
\hline
\end{tabular}

Table 4. Isolate details and their accession numbers

\begin{tabular}{cllll}
\hline S. No. & Accession numbers & Isolate No. & Pathotype & Species and place of sampling \\
\hline 1 & KT005220 & NJF1 & - & Jungle fowl, Nainital \\
2 & KT005221 & NCT2 & - & Caretaker, Nainital \\
3 & KT005222 & NGP4 & - & Golden pheasant, Nainital \\
4 & KT005223 & NW2 & - & Water, Nainital \\
5 & KT005224 & KCOK4 & - & Cockatiel, Nainital \\
6 & KT005225 & NCT5 & - & Caretaker, Nainital \\
7 & KT005226 & IHD4 & Atypical EPEC & Hog deer, IVRI \\
8 & KT005227 & KBB6 & ETEC & Black buck, Kanpur \\
9 & KT005228 & NBD2 & STEC & Barking deer, Nainital \\
10 & KT005229 & NL2 & Atypical EPEC & Leopard, Nainital \\
11 & KT005230 & KSCR2 & Atypical EPEC & Saras crane, Kanpur \\
12 & KT005231 & KW1 & STEC & Water, Kanpur \\
13 & KT005232 & PGRIASCT2 & Typical EPEC & Caretaker, PGRIAS \\
14 & KT005233 & IW1 & & - \\
15 & KT005234 & NJM1 & & Water, IVRI \\
16 & KT005235 & ICT1 & & Japanese macaque, Nainital \\
17 & KT005236 & KJ2 & STEC & Care taker, IVRI \\
18 & KT005237 & KN5 & STEC & Jackal, Kanpur \\
19 & KT005238 & KTD3 & STEC & Nilgai, Kanpur \\
20 & KT005239 & KRZ1 & & Tamin deer, Kanpur \\
21 & KT005240 & KHY5 & STEC & Rhinoceros, Kanpur \\
22 & KT005241 & PGRIASO5 & Typical EPEC & Hyena, Kanpur \\
23 & KT005242 & KCT4 & ETEC & Caretaker, Kanpur \\
\hline & & & & \\
\end{tabular}

typical EPEC, a common human pathogen [22], could be zoonotic sources of infection which were initially infected following direct or indirect contact with humans and domestic animals. To the best of our knowledge, based on the literature reviewed, this is the first report of EPEC in leopard, tiger, Himalayan bear, grey langur, bonnet macaque, swamp deer, hog deer, Indian peafowl, and saras crane.

In total, only 3 E. coli isolates were identified as ETEC. Two isolates were from caretakers and carried only the $l t$ gene and one isolate was recovered from blackbuck which carried the $s t I I$ gene $(5.88 \%)$. The true prevalence of ETEC is unknown due to the scarcity of studies in this area of disease biology. ETEC is a very common pathogen infecting piglets, calves, and travelers and is also thought to infect other important farm animals like horses, rabbits, and poultry, as these animals possess the ability to detect and respond to ETEC enterotoxins and adhesins [21]. While this is the first report of ETEC in blackbuck, a previous study carried out in China reported that E. coli isolated from farm-raised sika deer carried both the $l t$ and st genes at a frequency of 6.8\% [14].

Using 16S rRNA gene sequencing analysis, we determined that clustering was independent of pathotype. Notably, three different pathotypes (NL2-atypical EPEC, KW1- STEC, and KBB6-ETEC) clustered together. 16S rRNA sequencing analysis was found to be unsatisfactory in the monitoring of the relationships among strains. We suggest that pulsed-field gel electrophoresis (PFGE) or multi- 


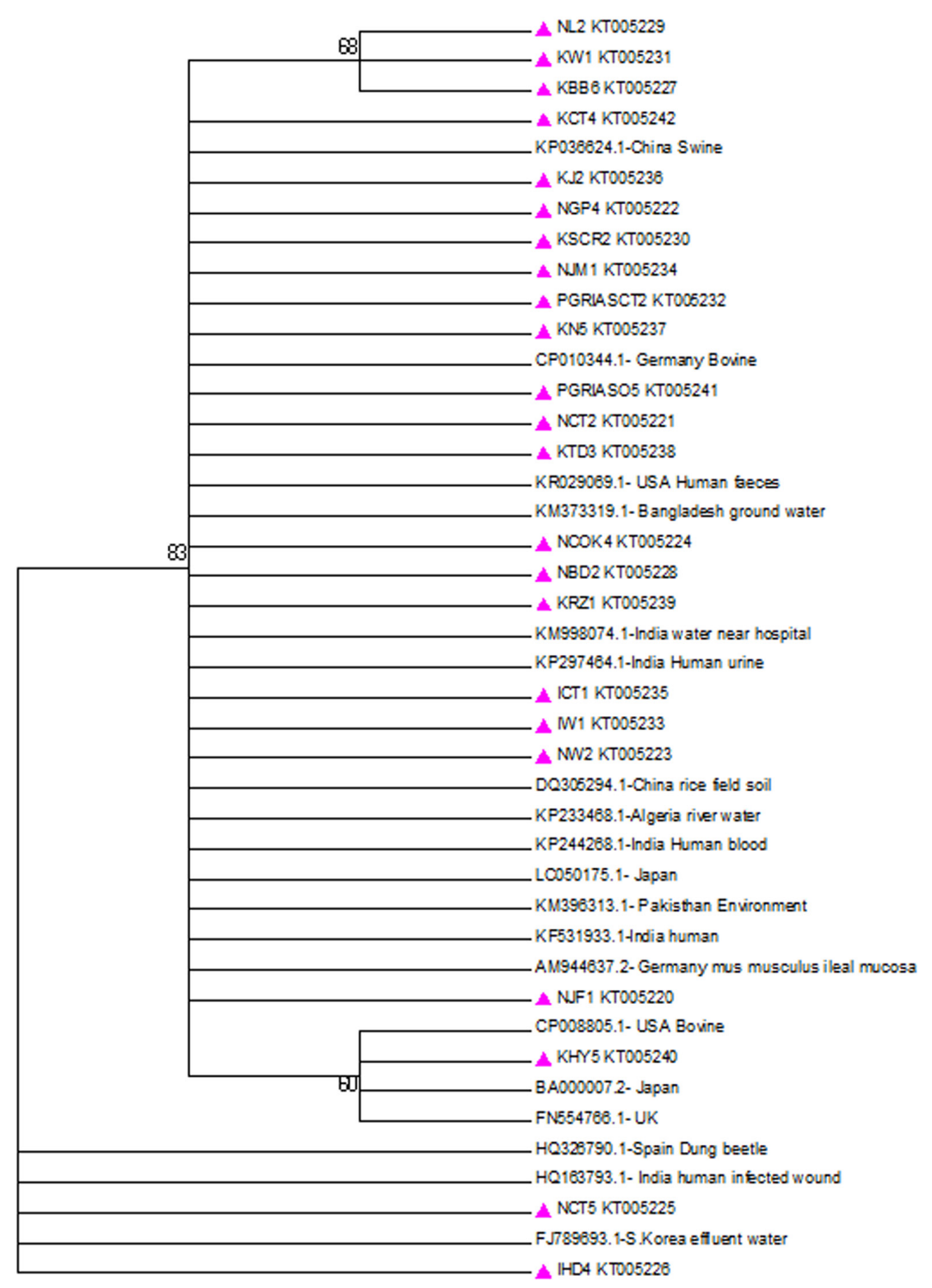

Fig. 1. Phylogenetic tree of E. coli isolates and their Genebank accession numbers.

locus sequence typing should be used to determine valid genetic variation among strains. However, our 16S rRNA gene sequencing analysis did reveal indiscriminate genetic profiling among the isolates of different animal species and their caretakers. The isolation of similar pathotypes (typical EPEC) from an ostrich (PGRIASO5) and its caretaker (PGRIASCT2) suggests the circulation of similar clones among captive wildlife and their caretakers. Thus, we suggest that as similar clones are circulated and maintained within captive wildlife, their caretakers, and their water sources, wildlife may serve as a reservoir for infection in humans and vice versa.

In conclusion, our study suggests that atypical EPEC strains are becoming more frequent than typical EPEC strains in captive wildlife, signifying that atypical EPEC strains have the potential to be a zoonotic pathogen. We observed a high frequency of STEC infection in captive wildlife and suggest that some measures to reduce the risk of exposure of caretakers and visitors at zoos should be implemented, as young children commonly visit zoos and other animal parks and are thus likely to become infected and potentially suffer severe complications such as HUS.

ACKNOWLEDGMENTS. The authors are grateful to the Director and Joint Directors (Academic and Research) of ICAR-IVRI, Izatnagar for providing the necessary facilities to carry out this research. The authors also thankfully acknowledge the cooperation and help provided by the zoo veterinarians, Dr. L.K. Sanwal (Nainital zoo), Dr. U.C. Srivastava, Dr. R.K. Singh (Kanpur zoo), and Prof. S.T. Selvan (PGRIAS, Chennai). 


\section{REFERENCES}

1. Adesiyun, A. A., Caeser, K. and Inder, L. 1998. Prevalence of Salmonella and Campylobacter infections in animals at Emperor Valley Zoo, Trinidad, American Association of Zoo Veterinarians. J. Zoo Wildl. Med. 29: 237-239. [Medline]

2. Bardiau, M., Grégoire, F., Muylaert, A., Nahayo, A., Duprez, J. N., Mainil, J. and Linden, A. 2010. Enteropathogenic (EPEC), enterohaemorragic (EHEC) and verotoxigenic (VTEC) Escherichia coli in wild cervids. J. Appl. Microbiol. 109: 2214-2222. [Medline] [CrossRef]

3. Carvalho, V. M., Gyles, C. L., Ziebell, K., Ribeiro, M. A., Catão-Dias, J. L., Sinhorini, I. L., Otman, J., Keller, R., Trabulsi, L. R. and Pestana de Castro, A. F. 2003. Characterization of monkey enteropathogenic Escherichia coli (EPEC) and human typical and atypical EPEC serotype isolates from neotropical nonhuman primates. J. Clin. Microbiol. 41: 1225-1234. [Medline] [CrossRef]

4. Cebula, T. A., Payne, W. L. and Feng, P. 1995. Simultaneous identification of strains of Escherichia coli serotype O157:H7 and their Shiga-like toxin type by mismatch amplification mutation assay-multiplex PCR. J. Clin. Microbiol. 33: 248-250. [Medline]

5. Chen, H. D. and Frankel, G. 2005. Enteropathogenic Escherichia coli: unravelling pathogenesis. FEMS Microbiol. Rev. 29: 83-98. [Medline] [CrossRef]

6. Croxen, M. A., Law, R. J., Scholz, R., Keeney, K. M., Wlodarska, M. and Finlay, B. B. 2013. Recent advances in understanding enteric pathogenic Escherichia coli. Clin. Microbiol. Rev. 26: 822-880. [Medline] [CrossRef]

7. Fukuyama, M., Yokoyama, R., Sakata, S., Furuhata, K., Oonaka, K., Hara, M., Satoh, Y., Tabuchi, K., Itoh, T., Kai, A. and Matsuda, M. 1999. [Study on the verotoxin-producing Escherichia coli--isolation of the bacteria from deer dung]. Kansenshogaku Zasshi 73: 1140-1144 (in Japanese). [Medline] [CrossRef]

8. Goffaux, F., China, B., Janssen, L. and Mainil, J. 2000. Genotypic characterization of enteropathogenic Escherichia coli (EPEC) isolated in Belgium from dogs and cats. Res. Microbiol. 151: 865-871. [Medline] [CrossRef]

9. Gyles, C. L. 2007. Shiga toxin-producing Escherichia coli: an overview. J. Anim. Sci. 85 Suppl: E45-E62. [Medline] [CrossRef]

10. Isidean, S. D., Riddle, M. S., Savarino, S. J. and Porter, C. K. 2011. A systematic review of ETEC epidemiology focusing on colonization factor and toxin expression. Vaccine 29: 6167-6178. [Medline] [CrossRef]

11. Krause, G., Zimmermann, S. and Beutin, L. 2005. Investigation of domestic animals and pets as a reservoir for intimin- (eae) gene positive Escherichia coli types. Vet. Microbiol. 106: 87-95. [Medline] [CrossRef]

12. Leotta, G. A., Deza, N., Origlia, J., Toma, C., Chinen, I., Miliwebsky, E., Iyoda, S., Sosa-Estani, S. and Rivas, M. 2006. Detection and characterization of Shiga toxin-producing Escherichia coli in captive non-domestic mammals. Vet. Microbiol. 118: 151-157. [Medline] [CrossRef]

13. Levine, M. M. and Edelman, R. 1984. Enteropathogenic Escherichia coli of classic serotypes associated with infant diarrhea: epidemiology and pathogenesis. Epidemiol. Rev. 6: 31-51. [Medline] [CrossRef]

14. Li, R., He, L., Hao, L., Wang, Q., Zhou, Y. and Jiang, H. 2013. Genotypic and phenotypic characterization of antimicrobial-resistant Escherichia coli from farm-raised diarrheic sika deer in Northeastern China. PLoS One 8: e73342. [Medline] [CrossRef]

15. Mansfield, K. G., Lin, K. C., Newman, J., Schauer, D., MacKey, J., Lackner, A. A. and Carville, A. 2001. Identification of enteropathogenic Escherichia coli in simian immunodeficiency virus-infected infant and adult rhesus macaques. J. Clin. Microbiol. 39: 971-976. [Medline] [CrossRef]

16. Miller, M. and Olea-Popelka, F. 2013. One Health in the shrinking world: experiences with tuberculosis at the human-livestock-wildlife interface. Comp. Immunol. Microbiol. Infect. Dis. 36: 263-268. [Medline] [CrossRef]

17. Milton, A. A. P., Agarwal, R. K., Bhuvana Priya, G., Saminathan, M., Aravind, M., Reddy, A., Athira, C. K., Ramees, T., Sharma, A. K. and Kumar, A. 2017. Prevalence and molecular typing of Clostridium perfringens in captive wildlife in India. Anaerobe 44: 55-57. [Medline] [CrossRef]

18. Prince Milton, A. A., Agarwal, R. K., Priya, G. B., Saminathan, M., Aravind, M., Reddy, A., Athira, C. K., Anjay., Ramees, T. P., Dhama, K., Sharma, A. K. and Kumar, A. 2017. Prevalence of Campylobacter jejuni and Campylobacter coli in captive wildlife species of India. Majallah-i Tahqiqat-i Dampizishki-i Iran 18: 177-182. [Medline]

19. Mishra, R. P., Jain, U. and Singh, R. K. 2016. Genotypic study of verocytotoxic Escherichia coli isolates from deer by multiplex polymerase chain reaction. Vet. World 9: 919-921. [Medline] [CrossRef]

20. Moura, R. A., Sircili, M. P., Leomil, L., Matté, M. H., Trabulsi, L. R., Elias, W. P., Irino, K. and Pestana de Castro, A. F. 2009. Clonal relationship among atypical enteropathogenic Escherichia coli strains isolated from different animal species and humans. Appl. Environ. Microbiol. 75: 7399-7408. [Medline] [CrossRef]

21. Nagy, B. and Fekete, P. Z. 2005. Enterotoxigenic Escherichia coli in veterinary medicine. Int. J. Med. Microbiol. 295: 443-454. [Medline] [CrossRef]

22. Nataro, J. P. and Kaper, J. B. 1998. Diarrheagenic Escherichia coli. Clin. Microbiol. Rev. 11: 142-201. [Medline] [CrossRef]

23. Qadri, F., Svennerholm, A. M., Faruque, A. S. G. and Sack, R. B. 2005. Enterotoxigenic Escherichia coli in developing countries: epidemiology, microbiology, clinical features, treatment, and prevention. Clin. Microbiol. Rev. 18: 465-483. [Medline] [CrossRef]

24. Reid, S. D., Herbelin, C. J., Bumbaugh, A. C., Selander, R. K. and Whittam, T. S. 2000. Parallel evolution of virulence in pathogenic Escherichia coli. Nature 406: 64-67. [Medline] [CrossRef]

25. Rhyan, J. C. and Spraker, T. R. 2010. Emergence of diseases from wildlife reservoirs. Vet. Pathol. 47: 34-39. [Medline] [CrossRef]

26. Sabat, G., Rose, P., Hickey, W. J. and Harkin, J. M. 2000. Selective and sensitive method for PCR amplification of Escherichia coli 16S rRNA genes in soil. Appl. Environ. Microbiol. 66: 844-849. [Medline] [CrossRef]

27. Saidenberg, A. B., Teixeira, R. H. F., Guedes, N. M. R., Allgayer, M. C., Melville, P. A. and Benites, N. R. 2012. Molecular detection of enteropathogenic Escherichia coli in asymptomatic captive psittacines. Pesqui. Vet. Bras. 32: 922-926. [CrossRef]

28. Sánchez, S., García-Sánchez, A., Martínez, R., Blanco, J., Blanco, J. E., Blanco, M., Dahbi, G., Mora, A., Hermoso de Mendoza, J., Alonso, J. M. and Rey, J. 2009. Detection and characterisation of Shiga toxin-producing Escherichia coli other than Escherichia coli O157:H7 in wild ruminants. Vet. J. 180: 384-388. [Medline] [CrossRef]

29. Sánchez, S., Martínez, R., Rey, J., García, A., Blanco, J., Blanco, M., Blanco, J. E., Mora, A., Herrera-León, S., Echeita, A. and Alonso, J. M. 2010. Pheno-genotypic characterisation of Escherichia coli O157:H7 isolates from domestic and wild ruminants. Vet. Microbiol. 142: 445-449. [Medline] [CrossRef]

30. Sekse, C., Sunde, M., Lindstedt, B. A., Hopp, P., Bruheim, T., Cudjoe, K. S., Kvitle, B. and Urdahl, A. M. 2011. Potentially human-pathogenic Escherichia coli O26 in Norwegian sheep flocks. Appl. Environ. Microbiol. 77: 4949-4958. [Medline] [CrossRef]

31. Sussman, M. 1997. Escherichia coli and human disease. In Escherichia coli mechanisms of virulence, M. Sussman (ed.) Cambridge University Press, New York, New York, pp. 3-48.

32. Trabulsi, L. R., Keller, R. and Tardelli Gomes, T. A. 2002. Typical and atypical enteropathogenic Escherichia coli. Emerg. Infect. Dis. 8: 508-513. [Medline] [CrossRef]

33. Vidal, R., Vidal, M., Lagos, R., Levine, M. and Prado, V. 2004. Multiplex PCR for diagnosis of enteric infections associated with diarrheagenic Escherichia coli. J. Clin. Microbiol. 42: 1787-1789. [Medline] [CrossRef]

34. Wick, L. M., Qi, W., Lacher, D. W. and Whittam, T. S. 2005. Evolution of genomic content in the stepwise emergence of Escherichia coli O157:H7. J. Bacteriol. 187: 1783-1791. [Medline] [CrossRef] 